\title{
Feeding, growth and metabolism of the marine heterotrophic dinoflagellate Gyrodinium dominans
}

\author{
Claire Schmoker ${ }^{1,4, *}$, Peter Thor ${ }^{2}$, Santiago Hernández-León ${ }^{1}$, Benni W. Hansen ${ }^{3}$ \\ ${ }^{1}$ Institute of Oceanography and Global Change, Universidad de Las Palmas de Gran Canaria, \\ Campus Universitario de Tafira, 35017 Las Palmas de Gran Canaria, Canary Islands, Spain \\ ${ }^{2}$ University of Gothenburg, Department of Marine Ecology, Kristineberg, 45178 Fiskebäckskil, Sweden \\ ${ }^{3}$ Department of Environmental, Social and Spatial Change, Roskilde University, 4000 Roskilde, Denmark \\ ${ }^{4}$ Present address: DHI Water and Environment, 200 Pandan Loop, \#08-03 Pantech 21, Singapore 128388
}

\begin{abstract}
Rates of grazing, growth, and respiration were studied in the heterotrophic dinoflagellate Gyrodinium dominans experiencing a single pulse of prey. Additionally, rates of grazing and growth were compared to those of $G$. dominans growing with constant concentrations of prey. The maximal specific growth rates of $G$. dominans with a single pulse of prey were similar to those observed when G. dominans was acclimated to constant levels of prey. Thus, our results support the hypothesis that the growth of G. dominans responds quickly to changes in the abundance of prey. Moreover, growth rates were negative when concentrations of prey were low; this would suggest that $G$. dominans is adapted to eutrophic conditions. Respiration rates were higher than growth rates when G. dominans was fed a single pulse of prey, and we hypothesize that the ability to respond numerically to a changing abundance of prey may inflict high metabolic costs. Gross growth efficiencies (GGEs), determined for G. dominans in both food availability conditions, were within the range of values reported for other heterotrophic protozoans, and while GGE decreased when concentrations of food were high in organisms fed a single pulse of food, the opposite was observed in organisms acclimatized to a constant level of food.
\end{abstract}

KEY WORDS: Heterotrophic dinoflagellate · Grazing · Growth · Respiration · GGE

\section{INTRODUCTION}

It is now well recognized that microzooplanktonciliates and heterotrophic dinoflagellates-are major consumers of pelagic primary production (Calbet \& Landry 2004). Moreover, the abundance and biomass of heterotrophic dinoflagellates are often comparable to, or in some cases exceed, that of ciliates in many planktonic ecosystems (Hansen 1991, Lessard 1991), and several studies emphasize the ecological importance of heterotrophic dinoflagellates (Lessard \& Swift 1985, Bjørnsen \& Kuparinen 1991, Hansen 1991, Strom 1991, Sherr \& Sherr 2007). Due to their significant grazing pressure, heterotrophic dinoflagellates are important regulators of phytoplankton production (Putland 2000), as well as significant conveyors of remineralization in the euphotic zone (Sherr \& Sherr 2000). Additionally, microscopic examination of the gut contents, feeding structures, and faecal material of invertebrates and fish larvae reveal that they consume microzooplankton, including heterotrophic dinoflagellates (Stoecker \& Capuzzo 1990, Hansen et al. 2010). Thus, these organisms act as an important trophic link between nanoplankton and the larger mesozooplankton and macrozooplankton (Gifford 1988).

The strength of the trophic link is controlled entirely by the intrinsic energetics of the dinoflagellates. The ratio between growth and grazing, i.e. the gross growth efficiency (GGE), determines the efficiency by which these organisms convert ingested matter into biomass and thus convey energy to the next trophic level. Accordingly, the efficiency of the food chain is the product of GGE and predation pres- 
sure. However, matter is lost at varying rates from each trophic level as it is transported up through the food web. Part of the ingested and assimilated matter is used for energy production in respiration before it is transported to the next level. The result is a balance between GGE and respiration, which controls the transport of energy to the upper food web. While the importance of GGE is obvious, the significance of respiration may be more obscure. As in metazoan grazers such as copepods (Thor et al. 2002), respiration rates may vary with the food conditions encountered, and they may, as a result, account for considerably varying portions of the total energy budget.

Information about the ecological role of heterotrophic dinoflagellates is now increasing (e.g. Hansen 1991, 1992, Strom 1991, Nakamura et al. 1992, Jacobson \& Anderson 1993, Strom \& Buskey 1993, Verity et al. 1993), and some literature exists on their grazing and growth (e.g. Strom 1991, Hansen 1992, Jeong et al. 2005). However, knowledge about the underlying energetics of trophic transport by dinoflagellates is still sparse in comparison to our knowledge of ciliates (e.g. Verity 1985, Bernard \& Rassoulzadegan 1990, Verity 1991). For instance, while Verity (1985) studied grazing, growth, excretion, and respiration in 2 tintinnid ciliate species, studies on Gyrodinium covered grazing and growth rates but unfortunately did not include respiration rates (Hansen 1992, Nakamura et al. 1992, 1995).

In the present study, we measured grazing, growth, and respiration rates in Gyrodinium dominans. Contrary to an earlier belief, the pelagic realm is not homogeneous (Andersen \& Sørensen 1986, Owen 1989, Franks 1995); steady-state conditions are rarely found in nature and, if they ever occur, are found only during short intervals of time. We therefore measured these variables in $G$. dominans exposed to a single pulse of food. Furthermore, to examine to what extent pulsed food conditions influence the energetics of the dinoflagellate we compared the growth of $G$. dominans on a single pulse of food with growth under constant food conditions.

\section{MATERIALS AND METHODS}

\section{Culture of the algal prey (Rhodomonas salina) and the heterotrophic dinoflagellate Gyrodinium dominans}

Rhodomonas salina was maintained in exponential growth in non-axenic B1 algal growth medium (Hansen 1992) at $17^{\circ} \mathrm{C}$ in a light period of $24 \mathrm{~h}$ at $\sim 150 \mu \mathrm{mol}$ photons $\mathrm{m}^{-2} \mathrm{~s}^{-1}$ with gentle bubbling. A stock culture of exponentially growing Gyrodinium dominans was kept on a plankton wheel $(75 \mathrm{~cm}$ diameter, rotation at $1 \mathrm{rpm}$ ) at high concentration levels $\left(\sim 3000\right.$ cells $\left.\mathrm{ml}^{-1}\right)$ at $17^{\circ} \mathrm{C}$ in a light period of $24 \mathrm{~h}\left(\sim 10 \mu \mathrm{mol}\right.$ photons $\left.\mathrm{m}^{-2} \mathrm{~s}^{-1}\right)$. G. dominans was fed every $24 \mathrm{~h}$ with excess $R$. salina.

\section{Experiments with a single pulse of prey}

Gyrodinium dominans was kept in 11 bottles at $17^{\circ} \mathrm{C}$ in a light period of $24 \mathrm{~h}\left(\sim 10 \mu \mathrm{mol}\right.$ photons $\mathrm{m}^{-2}$ $\mathrm{s}^{-1}$ ) on the plankton wheel (1 rpm). For several days prior to the 3 experiments with a single pulse of prey, the organisms were fed excess Rhodomonas salina once every morning. Most $R$. salina were removed by grazing during the $24 \mathrm{~h}$ between feeding events, and so the cultures had experienced pulsed feeding for several generations prior to the experiments. The last acclimation feeding event took place $24 \mathrm{~h}$ prior to the onset of the experiments.

For each experiment, 4 bottles (each $500 \mathrm{ml}$ ) were prepared with known concentrations of Rhodomonas salina, and a specific quantity of Gyrodinium dominans cells from the acclimation culture was added to obtain specific prey:predator concentration ratios (Table 1). The initial prey:predator biomass ratio was set at 2.1:1 in Expt 1, 2.7:1 in Expt 2 and 6.8:1 in Expt 3. Initial concentrations of $G$. dominans were higher than those observed in the field (Nakamura et al. $1992,1995)$ but concentrations were chosen to facilitate reliable measurements of respiration. Four control bottles (each $500 \mathrm{ml}$ ) containing only $R$. salina were similarly prepared in order to measure the growth of prey. All bottles were incubated on the plankton wheel for $48 \mathrm{~h}$. Light and temperature conditions were similar to those for the G. dominans stock culture (see above). The light level was kept low $\left(\sim 10 \mu \mathrm{mol}\right.$ photons $\left.\mathrm{m}^{-2} \mathrm{~s}^{-1}\right)$ to avoid excessive growth of the prey. To measure cell abundance, trip-

Table 1. Experiments with the heterotrophic dinoflagellate Gyrodinium dominans fed a single pulse of prey: average values $( \pm \mathrm{SD})$ of the initial abundance and biomass of the prey

(Rhodomonas salina) and of G. dominans in Expts 1 to 3

\begin{tabular}{|lllll|}
\hline & \multicolumn{2}{c}{ Abundance (cells ml ${ }^{-1}$ ) } & \multicolumn{2}{c|}{ Biomass $\left(\mu g \mathrm{C} \mathrm{l}^{-1}\right)$} \\
& R. salina & G. dominans & R. salina & G. dominans \\
\hline Expt 1 & $33565 \pm 3634$ & $2775 \pm 362$ & $1309 \pm 142$ & $608 \pm 41$ \\
Expt 2 & $41676 \pm 281$ & $2427 \pm 527$ & $1625 \pm 11$ & $599 \pm 148$ \\
Expt 3 & $40354 \pm 660$ & $1367 \pm 163$ & $1574 \pm 26$ & $232 \pm 20$ \\
& & & & \\
\hline
\end{tabular}


licate $20 \mathrm{ml}$ samples were pipetted from the bottles and measured in the particle counter (Coulter Multisizer M3). Measurements were taken every $2 \mathrm{~h}$ during the first $24 \mathrm{~h}$ and every 4 to $6 \mathrm{~h}$ for the remainder of the experiments.

Respiration rates of Gyrodinium dominans were measured at every sampling event in Expts 2 and 3. Oxygen consumption was monitored continually for $2 \mathrm{~h}$ in 1 bottle holding G. dominans and in a control bottle containing only Rhodomonas salina. This was accomplished using a Unisense Microrespiration System (Unisense A/S) submerged in a thermostatically controlled water bath at $17^{\circ} \mathrm{C}$ with the same light conditions as those used during the plankton wheel incubations (Jensen et al. 2006). The samples were pipetted from the incubation bottles and injected into $750 \mathrm{ml}$ chambers, and an oxygen microelectrode (OX 25) was inserted for the measurements. Oxygen concentrations were monitored by a computer every $30 \mathrm{~s}$ for $2 \mathrm{~h}$. The periods, each of $2 \mathrm{~h}$, were sufficiently short to avoid significant population changes during measurements but long enough to obtain a significant reduction in the oxygen concentration signal. Due to methodological constraints, respiration measurements could only be performed in the experiments involving a single pulse of prey.

\section{Experiments with a constant level of prey}

For each concentration of prey, 8 bottles (each $500 \mathrm{ml})-4$ grazing bottles for Gyrodinium dominans and 4 controls - were prepared with known concentrations of Rhodomonas salina, and a specific quantity of $G$. dominans cells from the culture was added to each of the 4 grazing bottles. All bottles were then run for $24 \mathrm{~h}$ on the plankton wheel (light and temperature as described in the section above). Cell concentrations and volumes of $G$. dominans and $R$. salina were measured initially (at time 0 ) and after 24 and $48 \mathrm{~h}$. The organisms were adapted to a constant level of food by exposing them to a high level of food during the $24 \mathrm{~h}$ before the start of the experiment. With this experimental design, the food concentration remained constant during the experiment. Thus, the first $24 \mathrm{~h}$ served as the acclimation period, and specific rates of G. dominans grazing and growth were calculated from the differences in cell concentrations between 24 and $48 \mathrm{~h}$. During the incubations, average $R$. salina biomass was between 25 and $1263 \mu \mathrm{gC} \mathrm{l}^{-1}$ after $24 \mathrm{~h}$ of acclimation (see Table 2), and initial abundances of $G$. dominans were $470 \pm 205$ cells $\mathrm{ml}^{-1}$.
Table 2. Experiments involving a constant level of prey: average values $( \pm \mathrm{SD})$ of the initial and final abundance and biomass of the prey (Rhodomonas salina), after the acclimation period of Gyrodinium dominans. Six initial levels of prey were used, varying from 714 to 36086 cells ml$^{-1}$

\begin{tabular}{|cccc|}
\hline \multicolumn{2}{|c}{ Abundance $\left(\right.$ cells ml $\left.{ }^{-1}\right)$} & \multicolumn{3}{c|}{ Biomass $\left(\mu g \mathrm{Cl}^{-1}\right)$} \\
After $24 \mathrm{~h}$ & After $48 \mathrm{~h}$ & After $24 \mathrm{~h}$ & After $48 \mathrm{~h}$ \\
\hline $714 \pm 171$ & $714 \pm 171$ & $25 \pm 6$ & $25 \pm 6$ \\
$7714 \pm 1571$ & $9114 \pm 3228$ & $270 \pm 55$ & $319 \pm 113$ \\
$8057 \pm 2600$ & $8600 \pm 4657$ & $282 \pm 91$ & $301 \pm 163$ \\
$7514 \pm 1628$ & $7371 \pm 4000$ & $263 \pm 57$ & $258 \pm 140$ \\
$13286 \pm 6257$ & $18971 \pm 10628$ & $465 \pm 219$ & $664 \pm 372$ \\
$36086 \pm 2171$ & $48343 \pm 5628$ & $1263 \pm 76$ & $1692 \pm 197$ \\
\hline
\end{tabular}

\section{Calculations}

The abundance and cell size of both Gyrodinium dominans and Rhodomonas salina were measured using an electronic particle counter (Coulter Multisizer M3). G. dominans cell volumes were calculated from the equivalent spherical diameter (ESD) output from the particle counter, and carbon contents were calculated using the Menden-Deuer \& Lessard (2000) carbon:volume relationship. The $R$. salina carbon content was assumed to be $39 \mathrm{pgC}$ cell $^{-1}$ (Kiørboe et al. 1985).

Specific growth rates of Gyrodinium dominans $\left(\mu, \mathrm{h}^{-1}\right)$ were calculated as:

$$
\mu=\frac{\ln \left(M_{2}\right)-\ln \left(M_{1}\right)}{t}
$$

where $M_{1}$ and $M_{2}$ are concentrations of $G$. dominans at the beginning and end of each incubation interval $\left(\mu \mathrm{gC} \mathrm{l}^{-1}\right)$, respectively, and $t$ is the sampling time interval (h). For comparison between the single pulse of prey and constant-prey experiments, specific growth rates from the single-pulse experiments were calculated as averages over 6 to $8 \mathrm{~h}$.

Specific grazing rates $\left(i, \mathrm{~h}^{-1}\right)$ were calculated as:

$$
i=\frac{-k_{\mathrm{grz}}+k_{\mathrm{cont}}}{M}
$$

where $k_{\text {grz }}$ is the difference in concentration of Rhodomonas salina before and after incubations in bottles containing Gyrodinium dominans $\left(\mu \mathrm{gC} \mathrm{l}^{-1}\right)$, $k_{\text {cont }}$ is the average of differences in $R$. salina concentration in control bottles before and after incubations $\left(\mu \mathrm{gC} \mathrm{l}^{-1}\right), M$ is the average of $G$. dominans concentration during incubations $\left(\mu \mathrm{gC} \mathrm{l}^{-1}\right)$.

Specific growth rates were fitted to a modified Michaelis-Menten growth model allowing negative growth at low prey concentrations (Jeong et al. 2007): 


$$
\mu_{\text {pred }}=\frac{\mu_{\text {max }}\left(C_{\mathrm{p}}-C^{\prime}\right)}{\mathrm{k}+\left(C_{\mathrm{p}}-C^{\prime}\right)}
$$

where $\mu_{\text {pred }}$ is the predicted specific growth rate, $\mu_{\max }$ is the maximum specific growth rate, $C_{\mathrm{p}}$ is the concentration of prey, $C^{\prime}$ is the concentration of prey when $\mu=0$, and $\mathrm{k}$ is a constant.

Specific grazing rates were fitted to a Holling type II functional response model:

$$
i_{\text {pred }}=\frac{i_{\max } C_{\mathrm{p}}}{K_{\mathrm{m}}+C_{\mathrm{p}}}
$$

where $i_{\text {pred }}$ is the predicted specific grazing rate, $i_{\max }$ is the maximum specific grazing rate, $C_{\mathrm{p}}$ is the concentration of prey, and $K_{\mathrm{m}}$ is the concentration of prey when $i_{\text {pred }}=i_{\text {max }} / 2$.

Specific respiration rates $\left(r, \mathrm{~h}^{-1}\right)$ were computed from the slope of the decrease in oxygen concentration in the $750 \mu$ l chamber during the incubation:

$$
r=\frac{12\left(\alpha-\alpha_{\text {control }}\right)}{V \bar{C}_{G}}
$$

where $\alpha$ is the slope of the decrease in oxygen tension $\left(\mu \mathrm{M} \mathrm{O}_{2} \mathrm{~h}^{-1}\right)$ in chambers with Gyrodinium dominans, $\alpha_{\text {control }}$ is the slope of the decrease in oxygen tension in control chambers holding only Rhodomonas salina, $V$ is the volume of the incubation chamber (1), and $C_{G}$ is the average concentration of Gyrodinium dominans during the $2 \mathrm{~h}$ incubation period $\left(\mu \mathrm{gC} \mathrm{l}^{-1}\right)$. We assumed equal bacterial concentrations in G. dominans and control bottles, so that subtraction of $\alpha_{\text {control }}$ removed interference from bacterial respiration as well as photosynthesis/respiration by $R$. salina. Furthermore, we assumed a respiratory quotient of 1 so that each $\mu \mathrm{mol} \mathrm{O}_{2}$ respired equaled $1 \mathrm{~mol} \mathrm{CO}_{2}$ generated. Thus, the factor 12 constitutes the conversion from $\mu \mathrm{M} \mathrm{CO}_{2}$ to $\mu \mathrm{gC} \mathrm{l}^{-1}$.

To calculate the parameters of the energy budget in the experiments with a single pulse of prey, data were grouped in relation to food concentration: low

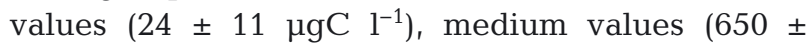
$\left.160 \mu \mathrm{gC}^{-1}\right)$ and high values $\left(1146 \pm 237 \mu \mathrm{gC}^{-1}\right)$ (see Table 3).
GGEs (\%) were calculated as $\mu / i \times 100$, and assimilation efficiencies $(\mathrm{AE}, \%)$ were calculated as $(\mu+r)$ $/ i \times 100$.

\section{RESULTS}

\section{Constant concentration of prey}

Specific grazing rates were significantly different among Rhodomonas salina concentrations (1-factor ANOVA: $F_{4,17}=65.2, \mathrm{p}<0.001$ ) (Fig. 1A). Interestingly, grazing rates decreased from $0.22 \mathrm{~h}^{-1}$ at $804 \mu \mathrm{gC} \mathrm{l}^{-1}$ to $0.11 \mathrm{~h}^{-1}$ at $1409 \mu \mathrm{gC} \mathrm{l}^{-1}$. We therefore applied the Holling type II functional response model only to the 4 lowest concentrations to extract meaningful values for $i_{\max }$ and $K_{\mathrm{m}}$.

Specific growth rates were also significantly different among prey concentrations (1-factor ANOVA: $\left.F_{4,17}=5.75, \mathrm{p}=0.007\right)$. The modified Holling type II functional response model fitted the relationship between growth and prey concentration with a $\mu_{\max }$ of $0.05 \pm 0.02 \mathrm{~h}^{-1}$, whereas $K_{\mathrm{m}}$ was $715 \pm 570 \mu \mathrm{gC} \mathrm{l}^{-1}$ (Fig. 1B). GGEs ranged from -0.13 to 0.28 , with the highest values at the highest prey concentrations (1409 $\mathrm{\mu gC}^{-1}$ ) (Fig. 1C).

\section{Experiments with a single pulse of prey}

Abundance and biomass of the Rhodomonas salina prey decreased during the incubation period in all 3 experiments (Fig. 2A) so that Gyrodinium dominans experienced a pulse of prey with concentrations $>200 \mu \mathrm{gC}^{-1}$ for $16 \mathrm{~h}$ in Expt 2, $28 \mathrm{~h}$ in Expt 1, and $37 \mathrm{~h}$ in Expt 3.

After an initial decrease during the first 8 to $10 \mathrm{~h}$, the abundance of Gyrodinium dominans increased significantly in all 3 experiments (linear regressions on G. dominans biomass vs. time-Expt 1: $\mathrm{r}^{2}=0.818$,

Table 3. Gyrodinium dominans. Energy budget in the experiments with a single pulse of prey. $C_{\mathrm{p}}=$ biomass of the prey (Rhodomonas salina), $i=$ specific grazing rate, $\mu=$ specific growth rate of $G$. dominans, $r=$ specific respiration rate, GGE $=$ gross growth efficiency, $\mathrm{AE}=$ assimilation efficiency. GGE was calculated as $\mu / i \times 100$, and AE as $(\mu+r) / i \times 100$

\begin{tabular}{|lcccccc}
\hline $\begin{array}{l}\text { Concentration } \\
\text { of } R \text {. salina }\end{array}$ & $\begin{array}{c}C_{\mathrm{p}} \\
\left(\mu \mathrm{gC} \mathrm{l}^{-1}\right)\end{array}$ & $\begin{array}{c}\mathrm{i} \\
\left(\mathrm{h}^{-1}\right)\end{array}$ & $\begin{array}{c}\mu \\
\left(\mathrm{h}^{-1}\right)\end{array}$ & $\begin{array}{c}r \\
\left(\mathrm{~h}^{-1}\right)\end{array}$ & $\begin{array}{c}\mathrm{GGE} \\
(\%)\end{array}$ & $\begin{array}{c}\mathrm{AE} \\
(\%)\end{array}$ \\
\hline High & $1146 \pm 237$ & $0.420 \pm 0.014$ & $0.025 \pm 0.021$ & $0.080 \pm 0.000$ & $6 \pm 6$ & $25 \pm 6$ \\
Medium & $650 \pm 160$ & $0.122 \pm 0.059$ & $0.025 \pm 0.033$ & $0.058 \pm 0.028$ & $30 \pm 13$ & $76 \pm 24$ \\
Low & $24 \pm 11$ & $0.135 \pm 0.024$ & $0.005 \pm 0.010$ & $0.095 \pm 0.031$ & $17 \pm 24$ \\
\hline
\end{tabular}




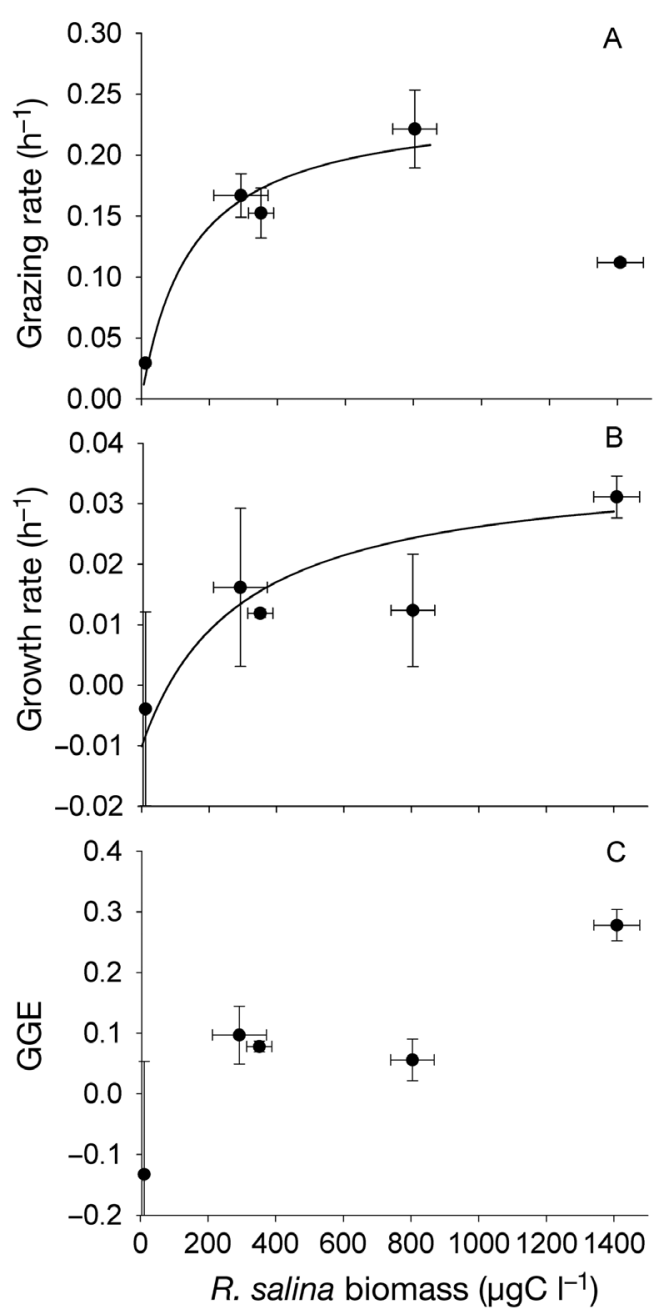

Fig. 1. Experiments with a constant concentration of prey. (A) Specific grazing rates of Gyrodinium dominans on the prey (Rhodomonas salina) (means $\pm \mathrm{SD}$ ). Parameters of the fitted model (Eq. 4) are $i_{\max }=0.24 \pm 0.03, K_{\mathrm{m}}=146 \pm 65$ $($ mean $\pm \mathrm{SD}), \mathrm{r}^{2}=0.96$. The outlier was not considered in the regression line. (B) Specific growth rates of G. dominans (means $\pm \mathrm{SD}$ ). Parameters of the fitted model (Eq. 3) are $\mu_{\max }$ $=0.036 \pm 0.011, \mathrm{k}=370 \pm 236$, and $C^{\prime}=79.8 \pm 38.2, \mathrm{r}^{2}=0.64$. (C) Gross growth efficiency (GGE) calculated as specific growth rate/specific grazing rate (means $\pm \mathrm{SD}$ )

$\mathrm{p}<0.001$; Expt 2: $\mathrm{r}^{2}=0.772, \mathrm{p}<0.001 ;$ Expt 3: $\mathrm{r}^{2}=$ 0.887, p < 0.001) (Fig. 2B). The initial decline in $G$. dominans could be explained by factors such as stress, adaptation to the new incubation bottles, or death because of experimental manipulations.

Fig. 2. Experiments with a single pulse of prey (Expts 1 to 3 ). Time series of average values $( \pm \mathrm{SE})$ of $(\mathrm{A})$ the biomass of Rhodomonas salina, (B) the abundance of Gyrodinium dominans and $(\mathrm{C})$ the prey:predator biomass ratio. (D) Average values $( \pm \mathrm{SE})$ of the biovolume of $G$. dominans as a function of the biomass of $R$. salina
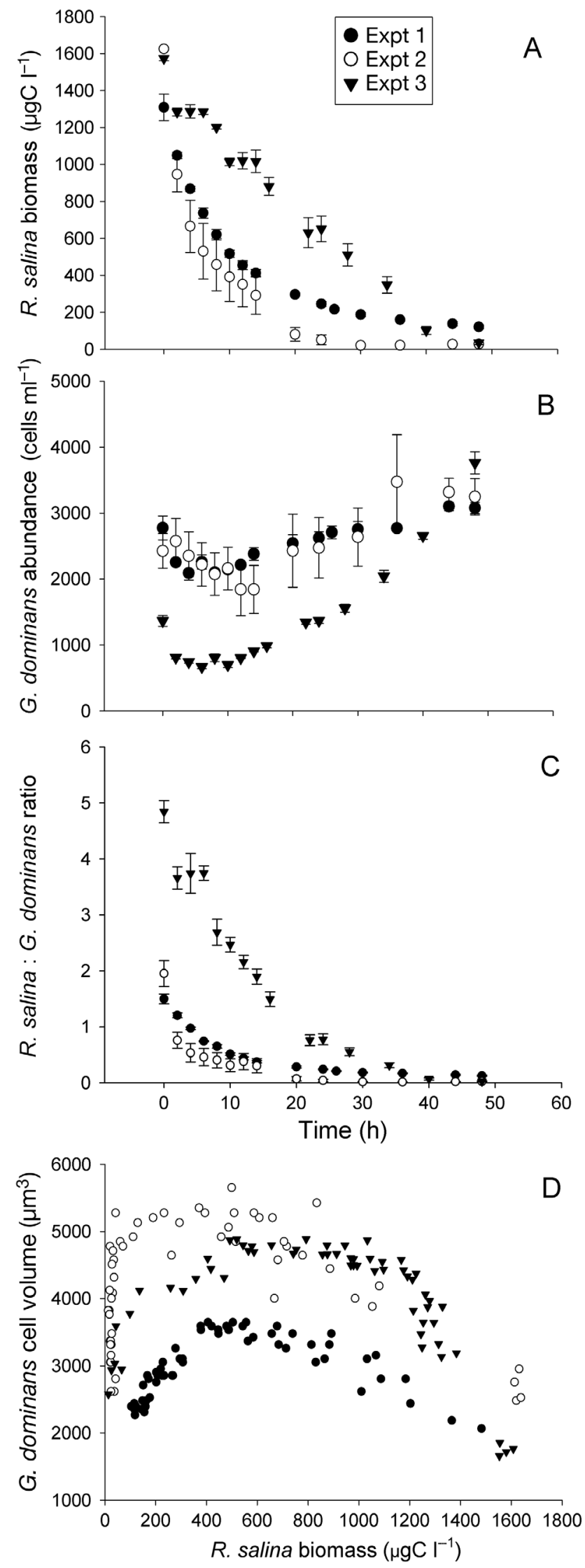
Ratios of prey:predator biomass decreased directly from the beginning in Expts 1 and 2, whereas in Expt 3 it remained high during the first $8 \mathrm{~h}$ and then decreased towards the end of the incubation period (Fig. 2C). these differences gave rise to different and significant biomass increases among the 3 experiments (1-factor ANOVA among slopes from linear regressions on biomass vs. time: $F_{2,43}=46.26$, $\mathrm{p}<0.001$ ).

The cell volume of Gyrodinium dominans increased during the first 8 to $10 \mathrm{~h}$ (increase: $197 \pm$ $67 \%$, mean \pm SD) and returned to the initial volume towards the end when concentrations of Rhodomonas salina fell below $200 \mu \mathrm{gC} \mathrm{l}^{-1}$. These differences in cell volume were significant (1-factor repeated measures ANOVA - Expt 1: $F_{14,59}=38.2$, $\mathrm{p}<0.001 ;$ Expt 2: $F_{13,55}=18.8, \mathrm{p}<0.001 ;$ Expt 3: $F_{14,59}$ $=13.2, \mathrm{p}<0.001$ ) (Fig. 2D). Cell volumes increased with specific grazing rates calculated from $8 \mathrm{~h}$ periods in Expts 1 and 2 and were correlated significantly in Expt 1 (linear regression: $r^{2}=0.382, p<0.01$ ).

Specific growth rates varied from ca. -0.01 to $0.03 \mathrm{~h}^{-1}$ in Expt 1, ca. -0.04 to $0.06 \mathrm{~h}^{-1}$ in Expt 2, and ca. 0.01 to $0.06 \mathrm{~h}^{-1}$ in Expt 3 (Fig. 3). To test for differences in the relationships between growth rates and prey concentrations between the 2 treatments (single pulse of prey and constant prey concentrations), we compared their functional responses (Fig. 3). This test showed no significant differences in the shape of the functional response (1-factor ANOVA on $R_{0}, R_{\max }$ and $\left.K_{\mathrm{m}}, \mathrm{p}>0.85\right)$. The initial concentrations of prey in both treatments were chosen to gain comparable growth rates between the 2 treatments (Fig. 3).

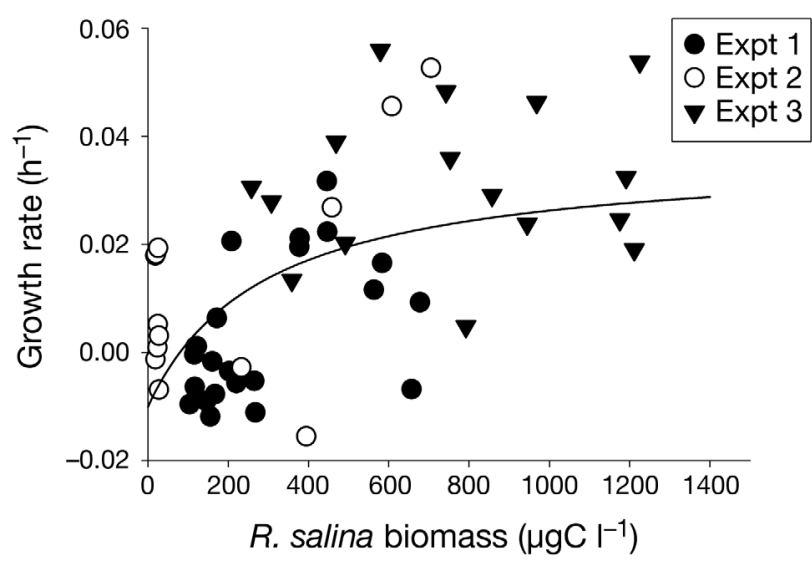

Fig. 3. Comparison of growth rates of Gyrodinium dominans between the 3 experiments involving a single pulse of prey and the experiment with a constant concentration of prey (continuous line). Growth rates with the single pulse of prey were calculated from distinct $8 \mathrm{~h}$ periods throughout the incubation period and plotted against the average concentration of Rhodomonas salina prey during those periods

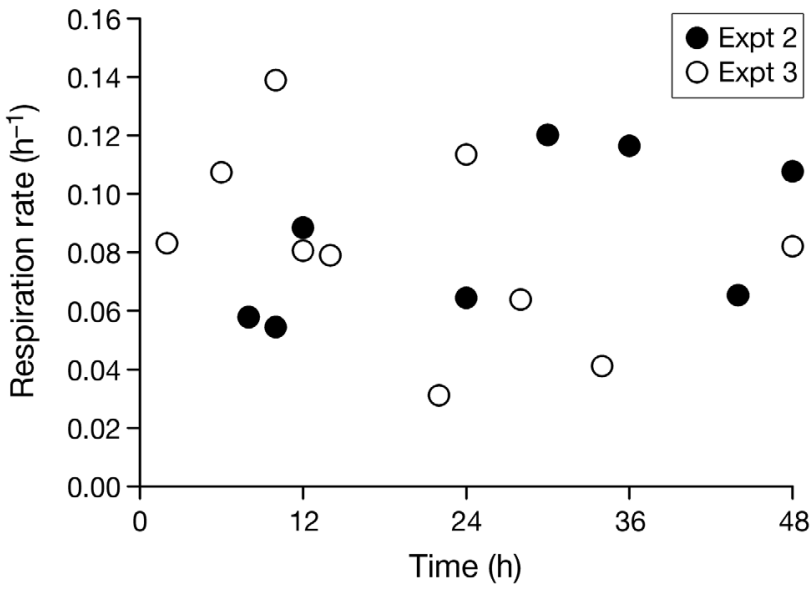

Fig. 4. Gyrodinium dominans. Non-steady-state experiments (Expts 2 and 3): specific respiration rate of $G$. dominans during the incubation period

Specific respiration rates showed no trend throughout the incubation periods but exhibited an average of $0.08 \pm 0.01 \mathrm{~h}^{-1}$ for Expts 2 and 3 (Fig. 4; linear regressions, slopes: $\mathrm{p}>0.05$ not shown on the figure). In order to assess a preliminary energetic budget of Gyrodinium dominans, we grouped the data in relation to food concentration: low values (18 to $39 \mu \mathrm{gC}$ $\mathrm{l}^{-1}$ ), medium values (469 to $656 \mu \mathrm{gC}^{-1}$ ) and high val-

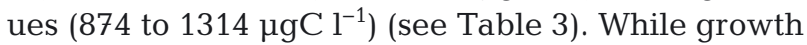
and respiration rates were low and similar, ingestion rates increased more than 3-fold when levels of food were high. GGE was the highest at a medium level of food.

\section{DISCUSSION}

\section{Specific growth rates at pulse feeding vs. constant food}

We found no significant differences in the patterns of specific growth rates between the 2 treatments. This observation confirms the assertion that heterotrophic dinoflagellate growth rates respond quickly to changes in food abundance and that they are well adapted to an environment with fluctuating concentrations of prey. Hansen (1991) concluded that heterotrophic dinoflagellates successfully track increases in phytoplankton biomass during bloom situations and may be able to control phytoplankton biomass (during the spring bloom, for example) significantly better than mesozooplankton grazers. This ability is probably common in microzooplankton, as was shown for ciliates by Montagnes (1996) and Montagnes \& Lessard (1999). These authors sug- 
gested that many planktonic ciliates can exploit patches of food and that their survival is dependent on the occurrence of such patches.

The numerical response of Gyrodinium dominans acclimated to a constant algal concentration showed negative growth rates at prey concentrations $<200 \mu \mathrm{gC} \mathrm{l}^{-1}$. Thus, although G. dominans may be well adapted to fluctuations in food concentration, it is probably also adapted to relatively eutrophic conditions. At food concentrations between 200 and $400 \mu \mathrm{gC}^{-1}$, we observed a major increase in the growth of G. dominans. $\mu_{\max }=0.05 \mathrm{~h}^{-1}$ is in accordance with data from the literature for this species or other heterotrophic dinoflagellates that feed on Rhodomonas salina (Strom 1991, Hansen 1992, Jakobsen \& Hansen 1997).

\section{Respiration}

In metazoans, respiration is often coupled to the rate of growth through the specific dynamic action (SDA). The SDA is the result of an elevated energy demand for the integrated physical and physiological process of feeding (Jobling 1983, Kiørboe et al. 1985, Brown \& Cameron 1991). Accordingly, the respiration rate is tightly coupled to both ingestion and growth rates in marine pelagic copepods (Thor 2000, 2002, Thor et al. 2002). However, in our study, respiration rates of non-steady-state Gyrodinium dominans were not significantly coupled to specific growth rates and remained fairly constant during the experiments. Moreover, specific respiration rates seemed to be higher than specific growth rates, which suggests an enhanced energy demand from acclimatization to the pulsed food concentrationsuggesting, in turn, that pulsed prey conditions may be metabolically demanding. Thus, despite the apparent adaptation to fluctuating concentrations of food, there is a significant loss of energy during these fluctuating conditions.

\section{Energy budget}

A preliminary energy budget for a microzooplanktonic dinoflagellate was built using the physiological parameters obtained. A striking result of our study was the high assimilation efficiency at the lower levels of food (Table 3). With this behavior, the organisms can have a better assimilation efficiency at low vs. high concentrations of food, thereby optimizing their metabolism at low energy levels.
The GGE ratio is the fraction of prey carbon that is consumed and converted to body mass; it gives an estimate of the success of an organism in converting ration to biomass. In a review of the GGE of different taxonomic groups - from protozoans to metazoans Straile (1997) concluded that mean and median values for all taxa scatter between 20 and $30 \%$. Hansen et al. (1997), in their review on zooplankton (of 2 to $2000 \mu \mathrm{m}$ body size), found values of $33 \pm 3 \%$. GGEs determined here for Gyrodinium dominansunder both conditions of food availability — are within the range of values reported for other heterotrophic protozoans (Caron et al. 1990). However, while GGE decreased with high concentrations of food in organisms exposed to a single pulse of food, the opposite was observed in organisms acclimatized to a constant level of food. In ciliates, GGEs generally decrease with increasing algal concentration (Verity 1985, Jonsson 1986, Strom 1991). This means that the success of an organism transferring phytoplankton carbon is higher when food is scarce, and this observation is in accordance with our energy budget. In contrast, the observation that GGE increases with food concentration when the organisms are exposed to a constant level of food is similar to the results for ciliates reported by Montagnes \& Lessard (1999) for ciliates.

\section{Evaluation of methodology}

A source of variability in our experiments was related to the fact that both cultures of food and predator were not axenic. However, this is the procedure used in most studies on growth and grazing of dinoflagellates or ciliates (e.g. Hansen 1992, Nakamura et al. 1992, 1995, Strom \& Buskey 1993, Jakobsen \& Hansen 1997). This is because the optimal food source for small heterotrophic Gyrodinium dominans are organisms belonging to the nanoplankton (Hansen 1992). Nakamura et al. (1995) showed that growth rates of $G$. dominans feeding upon bacterial flocks showed the highest rates recorded for this dinoflagellate, but organisms fed with only freeliving bacteria could not sustain growth. In our experiments, freely swimming bacteria may have been present but we argue that bacterial flocks did not form due to the short incubation periods.

\section{Concluding remarks}

In summary, our time-based experiments showed an increase in cell volume of Gyrodinium dominans 
fed a single pulse of food. Cell volume decreased below a given concentration of prey concurrently with the increase in abundance of cells. Logically, this may be a result of cell division. It seems that the onset of cell division may relate to some specific concentration of prey because we observed decreased average cell volumes when concentrations of Rhodomonas salina decreased below $400 \mu \mathrm{gC} \mathrm{l}^{-1}$ in all 3 experiments. Gyrodinium spp. have the ability to adopt a swarmer strategy when they experience starvation; they produce small and fast swimming individuals when concentrations of food are low (Hansen 1992). Moreover, at the highest levels of food, the ingestion rate was the highest, while the mean growth rate was higher with medium levels of food. These results also support the suggestion that G. dominans responds quickly to changes in abundance of food. Finally, the energy budget of these organisms behaves similarly to the one found for other heterotrophs, suggesting that they should be normally adapted to poor feeding conditions, but can also efficiently exploit the occasional finding of concentrated patches of food.

Acknowledgements. The authors thank H. H. Jakobsen for providing cultures of Gyrodinium dominans and for support on experimental designs. This study was funded, in part, by project 'Lucifer' (CTM2008-03538) from the Ministry of Science and Innovation of Spain, by a PhD fellowship to C.S. from the Government of the Canary Islands, Spain, by The Swedish Research Council for Environment, Agricultural Sciences, and Spatial Planning grant to P.T. (grant no. 20042484), and by The Danish National Science Research Council (grant no. 272-07-0485 awarded to B.W.H.).

\section{LITERATURE CITED}

Andersen P, Sørensen HM (1986) Population dynamics and trophic coupling in pelagic microorganisms in eutrophic coastal waters. Mar Ecol Prog Ser 33:99-109

> Bernard C, Rassoulzadegan F (1990) Bacteria or microflagellates as a major food source for marine ciliates: possible implications for the microzooplankton. Mar Ecol Prog Ser 64:147-155

Bjørnsen PK, Kuparinen J (1991) Growth and herbivory by heterotrophic dinoflagellates in the southern ocean, studied by microcosm experiments. Mar Biol 109: 397-405

Brown CR, Cameron JN (1991) The relationship between specific dynamic action (SDA) and protein synthesis rates in the Channel catfish. Physiol Zool 64:298-309

Calbet A, Landry MR (2004) Phytoplankton growth, microzooplankton grazing, and carbon cycling in marine systems. Limnol Oceanogr 49:51-57

Caron DA, Goldman JC, Fenchel T (1990) Protozoan respiration and metabolism. In: Capriulo GM (ed) Ecology of marine protozoa. Oxford University Press, New York, NY, p 307-322
Franks PJS (1995) Thin layers of phytoplankton: a model of formation by near-interstitial wave shear. Deep-Sea Res 42:75-91

Gifford DJ (1988) Impact of grazing by microzooplankton in the Northwest Arm of Halifax Harbor, Nova Scotia. Mar Ecol Prog Ser 47:249-258

> Hansen BW, Jacobsen HH, Andersen A, Almeda R, Pedersen TM, Christensen AM, Nilsson B (2010) Swimming behavior and prey retention of the polychaete larvae Polydora ciliata (Johnston). J Exp Biol 213:3237-3246

Hansen PJ (1991) Quatitative importance and trophic role of heterotrophic dinoflagellates in a coastal pelagial food web. Mar Ecol Prog Ser 73:253-261

Hansen PJ (1992) Prey size selection, feeding rates and growth dynamics of heterotrophic dinoflagellates with special emphasis on Gyrodinium spirale. Mar Biol 114: 327-334

Hansen PJ, Bjørnsen PK, Hansen BW (1997) Zooplankton grazing and growth: scaling within the 2- to 2000- $\mu \mathrm{m}$ body size range. Limnol Oceanogr 42:687-704

Jacobson DM, Anderson DM (1993) Growth and grazing rates of Protoperidium hirobis Abé, a thecate heterotrophic dinoflagellate. J Plankton Res 15:723-736

Jakobsen HH, Hansen PJ (1997) Prey size selection, grazing and growth response of the small heterotrophic dinoflagellate Gymnodinium sp. and the ciliate Balanion comatum-a comparative study. Mar Ecol Prog Ser 158:75-86

Jensen TC, Anderson TR, Daufresne M, Hessen DO (2006) Does excess carbon affect respiration of the rotifer Brachionus calyciflorus Pallas? Freshw Biol 51:2320-2333

Jeong HJ, Yoo DY, Seong KA, Kim JH and others (2005) Feeding by the mixotrophic red-tide dinoflagellate Gonyaulax polygramma: mechanisms, prey species, effects of prey concentration, and grazing impact. Aquat Microb Ecol 38:249-257

Jeong HJ, Kim JS, Song JY, Kim JH, Kim TH, Kim SK, Kang NS (2007) Feeding by protists and copepods on the heterotrophic dinoflagellates Pfiesteria piscicida, Stoeckeria algicida, and Luciella masanensis. Mar Ecol Prog Ser 349:199-211

> Jobling M (1983) Towards an explanation of specific dynamic action. J Fish Biol 23:549-555

Jonsson PR (1986) Particle size selection, feeding rates and growth dynamics of marine planktonic oligotrichous ciliates (Ciliophora Oligotrichina). Mar Ecol Prog Ser 33: 265-277

> Kiørboe T, Møhlenberg F, Hamburger K (1985) Bioenergetics of the planktonic copepod Acartia tonsa: relation between feeding, egg production and respiration, and composition of specific dynamic action. Mar Ecol Prog Ser 26:85-97

Lessard EJ (1991) The trophic role of heterotrophic dinoflagellates in diverse marine environments. Mar Microb Food Webs 5:49-58

> Lessard EJ, Swift E (1985) Species-specific grazing rates of heterotrophic dinoflagellates in oceanic waters, measured with a dual-label radioisotope technique. Mar Biol 87:289-296

> Menden-Deuer S, Lessard EJ (2000) Carbon-to-volume relationships for dinoflagellates, diatoms, and other protist plankton. Limnol Oceanogr 45:569-579

Montagnes DJS (1996) Growth responses of planktonic ciliates in the genera Strobilidium and Strombidium. Mar Ecol Prog Ser 130:241-254 
Montagnes DJS, Lessard EJ (1999) Population dynamics of the marine planktonic ciliate Strombidinopsis multiauris: its potential to control phytoplankton blooms. Aquat Microb Ecol 20:167-181

Nakamura Y, Yamazaki Y, Hiromi J (1992) Growth and grazing of a heterotrophic dinoflagellate, Gyrodinium dominans, feeding on a red tide flagellate, Chattonella antiqua. Mar Ecol Prog Ser 82:275-279

Nakamura Y, Suzuki SY, Hiromi J (1995) Growth and grazing of a naked heterotrophic dinoflagellate Gyrodinium dominans. Aquat Microb Ecol 9:157-164

Owen RW (1989) Microscale and finescale variations of small plankton in coastal and pelagic environmnents. J Mar Res 47:197-240

Putland JN (2000) Microzooplankton herbivory and bacterivory in Newfoundland coastal waters during spring, summer, and winter. J Plankton Res 22:253-277

Sherr EB, Sherr BF (2000) Marine microbes - an overview. In: Kirchmann DL (ed) Microbial ecology of the oceans. Wiley AJ, New York, NY, p 13-46

Sherr EB, Sherr BF (2007) Heterotrophic dinoflagellates: a significant component of microzooplankton biomass and major grazers of diatoms in the sea. Mar Ecol Prog Ser 352:187-197

Stoecker DK, Capuzzo JM (1990) Predation on protozoa: its importance to zooplankton. J Plankton Res 12:891-908

Straile D (1997) Gross growth efficiencies of protozoan and metazoan zooplankton and their dependence on food

Editorial responsibility: Klaus Jürgens,

Rostock, Germany concentration, predator-prey weight ratio, and taxonomic group. Limnol Oceanogr 42:1375-1385

Strom SL (1991) Growth and grazing rates of the herbivorous dinoflagellate Gymnodinium sp. from the open subarctic Pacific Ocean. Mar Ecol Prog Ser 78:103-113

Strom SL, Buskey EJ (1993) Feeding, growth, and behavior of the thecate heterotrophic dinoflagellate Oblea rotunda. Limnol Oceanogr 38:965-977

Thor P (2000) Relationship between specific dynamic action and protein deposition in calanoid copepods. J Exp Mar Biol Ecol 245:171-182

> Thor P (2002) Specific dynamic action and carbon incorporation in Calanus finmarchicus copepodites and females. J Exp Mar Biol Ecol 272:159-169

> Thor P, Cervetto G, Besiktepe S, Ribera-Maycas E, Tang KW, Dam HG (2002) Influence of two different green algal diets on specific dynamic action and incorporation of carbon into biochemical fractions in the copepod Acartia tonsa. J Plankton Res 24:293-300

> Verity P (1985) Grazing, respiration, excretion, and growth rates of tintinnids. Limnol Oceanogr 30:1268-1282

> Verity PG (1991) Measurement and simulation of prey uptake by marine planktonic ciliates fed plastidic and aplastidic nanoplankton. Limnol Oceanogr 36:729-750

> Verity PG, Stoecker DK, Sieracki ME, Burkill PH, Edwards ES, Tronzo CR (1993) Abundance, biomass and distribution of heterotrophic dinoflagellates during the North Atlantic spring bloom. Deep-Sea Res 40:227-244

Submitted: June 14, 2010; Accepted: August 2, 2011

Proofs received from author(s): October 26, 2011 